\title{
Comparison of the Effects of Concha Radiofrequency Ablation Between Patients with and Without Allergic Rhinitis
}

\author{
Alt Konkaya Radyofrekans Uygulamasının Allerjik Rinit Olan ve Olmayan \\ Hastalarda Etkinliğinin Karşılaştırılması \\ - Imran Aydoğdu, ๑ Ali Alper Bayram \\ Bahçelievler State Hospital, Clinic of Otorhinolaryngology, Istanbul, Turkey
}

\section{Abstract}

Aim: To evaluate the effectiveness of radiofrequency (RF) ablation of the inferior tubinates in patients with and without allergic rhinitis.

Methods: A prospective study including 47 patients who underwent radiofrequency ablation. The patients were divided into two groups according to allergic rhinitis status. The sinonasal outcome test-22 (SNOT-22), peak nasal flowmetry and the "Connecticut Chemosensory Clinical Research Center" test were administered in all patients before and after surgery.

Results: Thirty-four patients with allergic rhinitis and 13 without were assessed. Both groups showed a significant improvement in SNOT-22 scores, peak flowmeter results, and olfactory function after the procedure $(p<0.05)$. There was no significant difference between the groups for peak flowmeter results and olfactory function ( $p>0.05)$.

Conclusion: RF ablation has positive effects on nasal airflow, quality of life and olfaction in patients with and without allergic rhinitis. However, it would be useful to note that patient satisfaction would be less in patients with allergic rhinitis.

Keywords: Radiofrequency ablation, allergic rhinitis, smell test, questionnaire, SNOT-22
Öz

Amaç: Çalışmada alt konkaya radyofrekans (RF) uygulamasının allerjik riniti olan ve olmayan hastalarda etkinliğinin karşılaştırıması amaçlanmıştır.

Yöntemler: Çalışma alt konka RF ablasyon tedavisi uygulanan 47 hasta ile gerçekleştirildi. Hastalar alerjik rinit durumuna göre iki gruba ayrıldı. Hastaların tamamına işlem öncesi ve sonrası sinonasal outcome test-22 (SNOT-22) anketi, "Connecticut Kemosensör Klinik Araştırma Merkezi" koku testi ve nazal akım Ölçme yöntemi uygulandı.

Bulgular: Alerjik riniti olan 34 hasta ve olmayan 13 hasta değerlendirildi. Her iki grupta işlem sonrasında SNOT-22 skorlarında, nazal akış ölçer sonuçlarında ve koku alma fonksiyonlarında anlamlı iyileşme görüldü $(p<0,05)$. Gruplar arasında nazal flowmetre sonuçları ve koku alma fonksiyonu açısından anlamlı fark yoktu ( $p>0,05)$.

Sonuç: RF ablasyonunun alerjik riniti olan ve olmayan hastalarda nazal hava akımı, yaşam kalitesi ve koku alma üzerine olumlu etkileri vardır. Bununla birlikte, alerjik rinitli hastalarda hasta memnuniyetinin daha az olacağını not etmek faydalı olacaktır.

Anahtar Sözcükler: Radyofrekans, allerjik rinit, koku testi, anket, SNOT-22

\section{Introduction}

Chronic nasal obstruction is among the most common complaints encountered in otorhinolaryngology. Nasal obstruction has a variety of causes, including septum deviation, nasal polyps, nasal tumors, concha bullosa, and inferior turbinate hypertrophy. The most common of these is inferior turbinate hypertrophy (1). The main causes of inferior turbinate hypertrophy are allergic rhinitis, vasomotor rhinitis, and septum deviation (compensatory hypertrophy).

Allergic rhinitis is an inflammatory disorder of the nasal mucosa, mediated by $\lg E$ (2). Although it is not a severe
Address for Correspondence/Yazışma Adresi: İmran Aydoğdu, Bahçelievler State Hospital,

Clinic of Otolaryngology, İstanbul, Turkey

E-mail: imran_aydogdu@hotmail.com ORCID: orcid.org/0000-0002-7125-4978

Received/Geliş Tarihi: 26 November 2019 Accepted/Kabul Tarihi: 13 December 2019
${ }^{\circ}$ Copyright 2020 by The Medical Bulletin of istanbul Haseki Training and Research Hospital The Medical Bulletin of Haseki published by Galenos Yayınevi. ${ }^{8}$ Telif Hakkı 2020 istanbul Haseki Eğitim ve Araştırma Hastanesi Haseki Tıp Bülteni, Galenos Yayınevi tarafından yayınlanmıştır. 
disease, it negatively affects the patient's quality of life (3), causing symptoms such as nasal obstruction, pruritus, rhinorrhea, and sneezing. The diagnosis is based mainly on the clinical findings. However, skin prick tests or allergenspecific lgE tests may be helpful.

Regardless of the cause, the congestion due to inferior turbinate hypertrophy often resolves with medical treatment (4). Patients with nasal obstruction, who do not benefit from medical treatment, may respond to surgical treatment (5). One such treatment is radiofrequency (RF) ablation. RF ablation of the inferior turbinate is frequently used because of its successful results and low complication rates (6). Many studies have evaluated the improvement in nasal obstruction after RF ablation of the inferior turbinates. However, few studies have evaluated its effects on sense of smell, nasal airflow, and nasal symptomatology. Therefore, this study evaluated and compared the effectiveness of RF ablation of the inferior turbinates in patients with and without allergic rhinitis.

\section{Methods}

The study enrolled 47 patients, who underwent RF ablation for nasal obstruction and isolated inferior turbinate hypertrophy, and was approved by the ethics committee of istanbul Bakırköy Dr. Sadi Konuk Training and Research Hospital (approval no: 2017/384). All participants provided informed consent. All patients had inferior turbinate hypertrophy and nasal obstruction that had not responded to at least 2 months of topical nasal corticosteroids and systemic antihistamine treatment. Patients were excluded if they had previously undergone septoplasty, sinus surgery, or turbinate surgery, had recurrent rhinosinusitis, radiotherapy, concha bullosa, or choanal atresia, or were using oral steroids. None of the patients were smokers. All patients underwent a complete head and neck examination. Endoscopy was performed with $70^{\circ}$ and $0^{\circ}$ rigid endoscopes (TELECAM DX II; Karl Storz, Tuttlingen, Germany) and no additional nasal pathology was found in any patient. A detailed history that included age, gender, nasal obstruction, snoring, olfactory function, rhinorrhea, sneezing, and nasal itching was obtained from all patients. The patients were divided into two groups according to their clinical complaints. All patients in the group with allergic rhinitis (group 1) had a history allergic complaints, such as nasal itching, rhinorrhea and sneezing, and a positive skin prick test or a positive screening for immunoglobulin $\mathrm{E}(\mathrm{IgE})$. Patients in the nonallergic group (group 2) had no history of allergies, had negative skin prick test and a negative screening for $\lg \mathrm{E}$. Clinical diagnosis of allergic rhinitis was based on standard criteria (7).
The sinonasal outcome test-22 (SNOT-22), peak nasal flowmetry, and "Connecticut Chemosensory Clinical Research Center" (CCCRC) test were administered in all patients before and 8 weeks after surgery.

\section{Surgical Technique}

All the patients underwent RF ablation of the inferior turbinates performed by the same operator under local anesthesia with topical lidocaine (10 mg/dose) and 3-4 $\mathrm{mL}$ of $2 \%$ prilocaine hydrochloride injection before RF application. The Gyrus ENT G-1 TCRFTM generator was applied to the hypertrophic lower cone at $500{ }^{\circ} \mathrm{C}$ at an average energy of 1.5 Joules, at $75^{\circ} \mathrm{C}$ for RF application. When the inferior turbinate was very hypertrophic, $\mathrm{RF}$ was applied to the inferior concha at two different points. A paracetamol tablet was given when needed for postoperative pain. All patients were allowed to return to work or home on the same day. The patients were instructed to wash their nasal passages with isotonic saline solution postoperatively. The use of drugs that could affect the results, such as corticosteroids and antihistamines, was restricted.

\section{Obstruction and Smelling Function Assessment}

The SNOT-22, validated by Hopkins et al. (8), was used to evaluate sinonasal symptoms. Data were collected using a self-administered questionnaire. The SNOT-22 consists of 22 questions, with each question rated from 0 to 5; low scores indicate better results. At the end of week 8 , the results of the SNOT-22 were compared between patients with and without allergic rhinitis.

Peak nasal inspiratory flowmeter measurements were made using a nasal inspiratory flowmeter (Clement Clark International; Harlow, Essex, UK). After strong inspiration, the value obtained was expressed in $\mathrm{L} / \mathrm{min}$. The patients in a sitting position, after full exhalation, were asked to inspire strongly from the anesthesia mask placed over their mouth and nose. Of three consecutive measurements with a maximum difference of $10 \%$, the highest measurement was recorded as the final value.

The CCCRC test was performed using a commercially available test kit in an odor-free room under standardized conditions. The CCCRC test is composed of two sections: 1 ) identification of an odor and 2) detection of the threshold. All steps were carried out for each nasal passage, while the other nasal airway was obstructed. Detection of the threshold was measured with a series of bottles containing nine concentrations of n-butyl alcohol. The maximum concentration of n-butyl alcohol was $4 \%$ (bottle 0). Each subsequent bottle contained a three-fold dilution of n-butyl alcohol with deionized water. Each concentration was presented along with a water control in a doubleblind, forced-choice paradigm. The threshold was defined 
as the dilution at which the butanol bottle was correctly identified in four consecutive trials. Seven olfactory stimuli (baby powder, chocolate, cinnamon, coffee, mothballs, peanut butter, and soap) and three stimuli [ammonia, Vicks Vaporub (Eczacibasi Drug Co., İstanbul, Turkey), and wintergreen] were used to analyze the sensory function of the trigeminal nerve. Olfactory tests were conducted individually and were scored out of 7 (0: worst olfaction; 7: best olfaction) (9).

\section{Statistical Analysis}

The pre- and postoperative parameters were compared using SPSS software (ver. 17.0; SPSS Inc., Chicago, IL, USA). The mean values and standard deviation were calculated. The paired samples t-test was used to compare two dependent groups. The independent samples t-test was used to compare independent groups. The results were evaluated using the $95 \%$ confidence interval and the level of significance was accepted as $p<0.05$.

\section{Results}

The study included 47 patients, who complained of nasal obstruction, seen in the Bahçelievler State Hospital Ear, Nose and Throat Clinic: 34 (72.3\%) patients with allergic rhinitis (group 1) and 13 patients (27.6\%) with non- allergic rhinitis (group 2). Of the patients, 25 (53.2\%) were male and 22 (46.8\%) were female. The average patient age was 27.5 years (range: 19-43 years). No statistically significant difference was found between the groups in terms of age and gender.

The SNOT-22 was applied preoperatively and 8-week postoperatively in both groups. In the preoperative and postoperative assessments, the postoperative values were significantly different from the preoperative values in both groups. However, when the two groups were compared, the improvement in the group without allergic rhinitis was significantly higher than in the group with allergic rhinitis (Table 1).

When assessing the nasal airflow of patients preoperatively and postoperatively, a significant increase was seen in nasal airflow in both groups. However, when the two groups were compared, no difference was observed between them (Table 2).

In comparisons of smell function preoperatively and postoperatively, the smell function improved after surgery in both groups. However, when the two groups were compared, no difference was observed between them (Table 3).

\begin{tabular}{|l|l|l|l|}
\hline Table 1. Evaluation of SNOT-22 questionnaire in patients who underwent radiofrequency ablation \\
\hline SNOT-22 & $\begin{array}{l}\text { Pretreatment } \\
\text { Mean } \pm \text { SD }\end{array}$ & $\begin{array}{l}\text { Posttreatment } \\
\text { Mean } \pm \text { SD }\end{array}$ & $\begin{array}{l}\text { First-last change } \\
\text { tp }\end{array}$ \\
\hline Inferior turbinate hipertrohy with allergic rhinitis & $47.87 \pm 10.51$ & $39.67 \pm 9.44$ & 0.009 \\
\hline Inferior turbinate hipertrohy without allergic rhinitis & $46.12 \pm 9.47$ & $30.42 \pm 8.98$ & 0.004 \\
\hline${ }^{*} \mathbf{p}$ & 0.495 & 0.034 & - \\
\hline $\begin{array}{l}\text { SNOT-22: Sino-nasal outcome test-22, SD: Standard deviation } \\
{ }^{*} \text { Independent t-test, TPaired samples test, } \neq p<0.05\end{array}$ & & \\
\hline
\end{tabular}

\begin{tabular}{|l|l|l|l|}
\hline \multicolumn{3}{|l|}{ Table 2. Comparison of the peak nasal inspiratory flowmeter results of the radiofrequency ablation } \\
\hline PNIF & $\begin{array}{l}\text { Pretreatment } \\
\text { Mean } \pm \text { SD }\end{array}$ & $\begin{array}{l}\text { Posttreatment } \\
\text { Mean } \pm \text { SD }\end{array}$ & $\begin{array}{l}\text { First-last change } \\
\text { tp }\end{array}$ \\
\hline Inferior turbinate hipertrohy with allergic rhinitis & $79.33 \pm 24.32$ & $99.56 \pm 27.08$ & 0.012 \\
\hline Inferior turbinate hipertrohy without allergic rhinitis & $78.01 \pm 23.90$ & $110.56 \pm 32.84$ & 0.009 \\
\hline${ }^{*} \mathbf{p}$ & 0.421 & 0.211 & \\
\hline $\begin{array}{l}\text { PNIF: Peak nasal inspiratory flowmeter, SD: Standard deviation } \\
{ }^{*} \text { Independent } t \text {-test, Paired samples testi, } \neq p<0.05\end{array}$ & & \\
\hline
\end{tabular}

\begin{tabular}{|c|c|c|c|}
\hline Olfactory Test & $\begin{array}{l}\text { Pretreatment } \\
\text { Mean } \pm \text { SD }\end{array}$ & $\begin{array}{l}\text { Posttreatment } \\
\text { Mean } \pm \text { SD }\end{array}$ & $\begin{array}{l}\text { First-last change } \\
t_{p}\end{array}$ \\
\hline Inferior turbinate hipertrohy with allergic rhinitis & $3.11 \pm 0.43$ & $5.01 \pm 0.76$ & 0.002 \\
\hline Inferior turbinate hipertrohy without allergic rhinitis & $4.05 \pm 0.60$ & $7.10 \pm 0.62$ & 0.001 \\
\hline${ }^{*} \mathbf{p}$ & 0.376 & 0.465 & - \\
\hline
\end{tabular}




\section{Discussion}

The prevalence of allergic rhinitis in the community ranges from 9 to $42 \%$ (10). However, this rate is expected to be higher in patients complaining of nasal obstruction. Of the 47 patients who participated in our study, 34 $(72.3 \%)$ had allergic rhinitis, while 13 (27.3\%) did not. Allergic rhinitis is a syndrome characterized by symptoms such as nasal obstruction, rhinorrhea, nasal itching, and sneezing. These symptoms result from chronic nasal mucosal inflammation of allergic origin. The symptom that most affects the quality of life in this patient group is nasal obstruction.

Patients complaining of nasal obstruction constitute a significant proportion of all patients with isolated inferior turbinate hypertrophy. Several medical and surgical procedures have been described for correcting inferior turbinate hypertrophy. The ideal approach to inferior turbinate hypertrophy that does not respond to medical treatment is a surgical procedure that removes sufficient tissue volume (11). Numerous surgical procedures have been described for inferior turbinate hypertrophy, including cryosurgery, electrocautery, total or partial excision, and turbinoplasty. Despite satisfactory results, especially with total or partial excision, these interventions are often complicated by hemorrhage and crusting $(12,13)$. Reducing the inferior turbinate volume with RF ablation has become increasingly common and is often preferred because it does not require general anesthesia, can be performed in an outpatient clinic, swiftly clears the symptoms of nasal obstruction, and is repeatable. The only pathology in the nasal cavity in the patients included in our study was inferior turbinate hypertrophy. No patient had septum deviation. We compared patients in terms of their smell function, nasal airflow, and nasal symptomatology preoperatively and postoperatively. All parameters showed improvement in both groups. However, when the two groups were compared in terms of their nasal symptomatology, the improvement in the group without allergic rhinitis was significantly higher than in the group with allergic rhinitis. The surgeon should proceed with caution when managing patients with allergic rhinitis and turbinate hypertrophy. These patients are more likely to be less satisfied after RF ablation compared to patients without allergy.

In the RF treatment of inferior turbinate hypertrophy, early success rates of $86-100 \%$ have been reported (14). In 38 patients followed for 20 months, Seeger et al. (15) reported that $69 \%$ had a very good improvement and $29 \%$ had partial improvement. In a series of patients with inferior concha hypertrophy, Rhee et al. (16) achieved a $100 \%$ success rate with two or three RF applications. Many similar studies emphasize that the success of the process increases with the number of applications. The benefits of the procedure were not limited to nasal obstruction; allergic rhinitis symptoms other than nasal obstruction also improved. At the end of the 8 weeks, $70.5 \%$ of the patients complaining of rhinorrhea, nasal itching, and sneezing had partial or complete improvement. None of the preoperative symptoms differed statistically between the patients with and without allergic rhinitis.

The vast majority of reports on RF surgery for inferior turbinate hypertrophy focused on the safety and efficacy of the method. Some of these studies reported minimal complications. In a literature review, Kezirian et al. (17) found minor complications in only nine of 213 patients with inferior turbinate hypertrophy who underwent RF ablation, with a major complication rate of $0 \%$. Harsten (18) reported minor procedural complications in 15\% of patients who underwent RF and turbinectomy. The most common complication in these patients was crusting, although one patient complained of a decreased sense of smell. Studies done in many centers emphasize that RF treatment is less likely to have shortand long-term postoperative complications than other surgical techniques $(14,19)$. In our study, short-term bleeding occurred in four patients (8.5\%) and no other complications occurred.

\section{Conclusion}

RF ablation is effective for inferior turbinate hypertrophy in patients with and without allergic rhinitis, including those with non-obstructive symptoms such as nasal itching, rhinorrhea and sneezing. RF ablation also has positive effects on nasal airflow, quality of life and olfaction in both groups. However, it would be useful to note that patient satisfaction would be less in patients with allergic rhinitis.

\section{Authorship Contributions}

Concept: i.A. Design: I.A. Data Collection or Processing: A.A.B. Analysis or Interpretation: I.A. Literature Search: A.A.B. Writing: I.A.

Conflict of Interest: No conflict of interest was declared by the authors.

Financial Disclosure: The authors declared that this study received no financial support.

\section{References}

1. Lai VWS, Corey JP. The objective assessment of nasal patency. Ear Nose Throat J 1993;72:395-400.

2. Simons FE. Allergic rhinitis: recent advances. Pediatric Clinics of North America 1988;35:1053-74.

3. Nalebuff DJ. Allergic rhinitis. Otolaryngology Head and Neck Surgery. Philadelphia 1993:765-74. 
4. Schmeizer B, Katz S, Vidts G. Long-term efficacy of our surgical approach to turbinate hypertrophy. Am J Rhinol 1999;13:199201.

5. Lippert BM, Werner JA. Treatment of hypertrophied inferior turbinate. HNO 2000;48:267-74.

6. Coste A, Yona L, Blumen M. Radiofrequency is a safe and effective treatment of turbinate hypertrophy. Laryngoscope 2001;111:894-9.

7. Bousquet J, Van Cauwenberge P, Khaltaev N. Allergic rhinitis and its impact on asthma (ARIA). J Allergy Clin Immunol 2001;108:5174-334.

8. Hopkins C, Gillett S, Slack R, Lund VJ, Browne JP. Psychometric validity of the 22-item Sinonasal Outcome Test. Clin Otolaryngol 2009;34:447-54.

9. Cain WS, Gent JF, Goodspeed RB, Leonard G. Evaluation of olfactory dysfunction in the Connecticut Chemosensory Clinical Research Center Laryngoscope 1988;98:83-8.

10. Settipane RA, Charnock DR. Epidemiology of rhinitis: allergic and nonallergic. Clin Allergy Immunol 2007;19:23-34.

11. Cavaliere M, Mottola G, lemma M. Comparison of the effectiveness and safety of radiofrequency turbinoplasty and traditional surgical technique in treatment of inferior turbinate hypertrophy. Otolaryngol Head Neck Surg 2005;133:972-8.
12. Hol MK, Huizing EH. Treatment of inferior turbinate pathology: a review and critical evaluation of the different techniques. Rhinology 2000;38:157-66.

13. Friedman M, Tanyeri H, Lim J, Landsberg R, Caldarelli D. A safe, alternative technique for inferior turbinate reduction. Laryngoscope 1999;109:1834-7.

14. Utley DS, Goode RL, Hakim I. Radiofrequency energy tissue ablation for the treatment of nasal obstruction secondary to turbinate hypertrophy. Laryngoscope 1999;109:683-6.

15. Seeger J, Zenev E, Gundlach P, Stein T, Muller G. Bipolar radiofrequency induced thermotherapy of turbinanate hypertrophy:Pilot study and 20 months' follow-up. Laryngoscope 2003;113:130-5.

16. Rhee CS, Kim DY, Won TB, et al. Changes of nasal function after temperaturecontroled radiofrequency tissue volume rediction for the turbinate. Laryngoscope 2001:111:153-8.

17. Kezirian EJ, Powell NB, Riley RW, et al. Incidence of complication in radiofrequency treatment of the upper airway. Laryngoscope 2005;115:1298-304.

18. Harsten G. How we do it: Radiofrequency-turbinectomy for nasal obstruction symptoms. Clin Otolaryngol 2005;30:64-6.

19. Jackson LE, Koch RJ. Controversies in the management of inferior turbinate hypertrophy: A comprehensive review. Plast Reconstr Surg 1999;103:300-12. 